\title{
Pengaruh Pengembangan Karir dan Penempatan Terhadap Kepuasan Kerja yang Berdampak pada Kinerja Karyawan pada PT Sanco Perdika Pratama di Jakarta
}

\author{
Wahid Sumarjo \\ Universitas Primagraha, Serang, Banten, Indonesia \\ Email : wahidsumarjo@primagraha.ac.id
}

(Diterima: Desember 2021; Direvisi: Desember 2021; Dipublikasikan: Januari 2022)

\begin{abstract}
ABSTRAK
Penelitian ini bertujuan untuk mengetahui pengaruh pengembangan karir dan penempatan terhadap kepuasan kerja yang berdampak pada kinerja karyawan pada PT. Sanco Perdika Pratama di Jakarta. Metode yang digunakan adalah explanatory research dengan sampel sebanyak 98 responden. Teknik analisis menggunakan analisis statistik dengan pengujian regresi, korelasi, determinasi dan uji hipotesis. Hasil penelitian ini Pengembangan karir berpengaruh signifikan terhadap kepuasan kerja sebesar $38,8 \%$, uji hipotesis diperoleh signifikansi $0,000<0,05$. Penempatan berpengaruh signifikan terhadap kepuasan kerja sebesar 38,5\%, uji hipotesis diperoleh signifikansi $0,000<0,05$. Pengembangan karir dan penempatan secara simultan berpengaruh signifikan terhadap kepuasan kerja sebesar 49,5\%, uji hipotesis diperoleh signifikansi $0,000<0,05$.Kepuasan kerja berpengaruh signifikan terhadap kinerja karyawan sebesar 39,7\%, uji hipotesis diperoleh signifikansi $0,000<0,05$.
\end{abstract}

\section{Kata Kunci: Pengembangan Karir, Penempatan, Kepuasan Kerja, Kinerja Karyawan}




\section{PENDAHULUAN}

Dalam suatu organisasi sudah tentu memiliki tujuan yang ingin dicapai yang sering dinamakan kinerja. Kinerja karyawan secara umum adalah sebuah perwujudan kerja yang dilakukan oleh karyawan yang biasanya digunakan sebagai dasar atau acuan penilaian terhadap karyawan didalam suatu organisasi. Kinerja yang baik merupakan suatu langkah untuk menuju tercapainya tujuan organisasi oleh karena itu, kinerja juga merupakan sarana penentu dalam mencapai tujuan organisasi sehingga perlu diupayakan untuk meningkatkan kinerja karyawan.

Dalam melakukan aktivitasnya pasti memiliki tujuan yang hendak dicapai, untuk mencapai atau mewujudkan tujuan tersebut setiap perusahaan harus pandai dalam memilih strategi, terutama adalah perencanaan sumber daya manusia yang pada intinya adalah terfokus pada langkah-langkah tertentu yang diambil oleh manajemen. Atas tersedianya tenaga kerja yang tetap untuk menempati jabatan serta waktu yang tepat dalam rangka pencapaian tujuan dan berbagai sasaran yang ditetapkan. Mereka memandang kerja adalah sesuatu yang mulia sehingga faktor sumber daya manusia dalam pelaksanaan kerja tidak boleh diabaikan. Hal tersebut terlihat dari semakin kecilnya permintaan untuk memperhatikan aspek manusia bukan hanya fokus pada aspek teknologi dan ekonomi.

Perusahaan

meningkatkan

dalam melakukan suatu bentuk kegiatan yaitu penempatan tenaga kerja atau karyawan yang memiliki tingkat kompeten yang berbeda-beda. Perbedaan kemampuan ini ditentukan berdasarkan basil perekrutan (recruitment) dan kualifikasi (qualification) perusahaan. Bahkan untuk promosi jabatan itu sendiri ditentukan berdasarkan penampatan kerja itu sendiri. Penempatan kerja merupakan salah satu faktor penting yang tidak boleh diabaikan dalam mencapai tujuan perusahaan. Jika perusahaan salah menempatkan karyawan pada tempat yang bukan keahliannya maka kinerja karyawan tidak akan maksimal sehingga tujuan perusahaan tidak efektif dan tidak efisien. Kinerja dan penempatan karyawan sangat berpengaruh terhadap pencapaian tujuan perusahaan. Jika penempatan karyawan sesuai dengan keahliannya maka kinerja karyawan akan maksimal sehingga tujuan perusahaan dapat tercapai. Disamping itu, di dalam peningkatan tenaga kerja (karyawan) terdapat aspek lain demi tercapainya tujuan persahaan yaitu pengembangan karir karyawan (career development). Ketika karyawan melakukan hal yang serupa dan secara berulang-ulang, hal tersebut akan berdampak buruk yang selanjutnya karyawan tersebut akan mengalami kejenuhan dalam bekerja. Untuk mencegah hal tersebut terjadi pasti di perlukannya proses pengembangan karir karyawan. Yang dimana, menurut Hasibuan, Malayu SP, 2004:69 pengembangan karir adalah suatu usaha untuk meningkatkan kemampuan teknis, teoritis, konseptual dan moral karyawan sesuai dengan kebutuhan pekerjaan/jabatan melalui pendidikan dan latihan. Pelaksanaan sistem penempatan pegawai dalam suatu 
organisasi merupakan suatu kegiatan yang harus dilakukan dengan baik, karena dengan penempatan pegawai yang tepat, maka pegawai yang bersangkutan akan mengetahui ruang lingkup kerjanya dan dapat melaksanakan tugas yang diberikan kepadanya, sehingga beban tugas yang diberikan kepadanya dapat dipertanggung jawabkan. Penempatan pegawai ini dilakukan untuk mendapatkan tenaga kerja yang sesuai dengan apa yang diharapkan baik secara kualitas, kuantitas, dan secara ideal. Dengan kata lain penempatan kedudukan pegawai harus tepat sesuai dengan bidang keahlian, pembawaan, kecakapan, dan kemampuannya. Dalam penempatan pegawai sebaiknya selalu memperhatikan prinsip the right man in theright place and the right man behind right job. Hal ini penting mengingat penempatan pegawai pada suatu kedudukan akan mempengaruhi terhadap pelaksanaan pekerjaan.

Penempatan merupakan langkah yang diambil segera setelah terlaksananya fungsi rekrutmen. Seperti halnya fungsi rekrutmen, proses seleksi dan penempatan merupakan salah satu fungsi terpenting dalam manajemen sumber daya manusia, karena tersedia/tidaknya pekerja dalam jumlah dan kualitas yang sesuai dengan kebutuhan organisasi, diterima/tidaknya pelamar yang telah lulus proses rekrutmen, tepat/tidaknya penempatan seorang pekerja pada posisi tertentu, sangat ditentukan oleh fungsi seleksi dan penempatan ini. Jika fungsi ini tidak terlaksanakan dengan baik maka dengan sendirinya akan berakibat fatal terhadap pencapaian tujuantujuan organisasi.

Penempatan menurut Sondang (2009), jika seluruh proses seleksi telah ditempuh dan lamaran seseorang diterima, akhirnya seseorang memperoleh status sebagai pegawai dan ditempatkan pada posisi tertentu untuk melaksanakan tugas atau pekerjaan tertentu pula. Penempatan tidak hanya berlaku bagi para pegawai baru, akan tetapi berlaku pula bagi para pegawai lama yang mengalami alih tugas dan mutasi.

Dikatakan kepuasan kerja menyebabkan peningkatan kinerja sehingga pekerja yang puas akan lebih produktif. Kepuasan kerja itu penting dipelajari dalam kajian perilaku organisasi, karena dengan mengetahui kepuasan kerja maka akan memudahkan bagi organisasi untuk mengembangkan organisasinya tersebut.

Pentingnya kepuasan kerja karyawan terhadap pekerjaannya sangat mempengaruhi output pekerjaannya. Kepuasan kerja menjadi masalah yang cukup menarik dan penting karena terbukti besar manfaatnya baik bagi kepentingan individu, perusahaan atau organisasi. Bagi individu, penelitian tentang sebab-sebab dan sumber-sumber kepuasan kerja memungkinkan timbulnya usaha-usaha peningkatan kebahagian taraf hidup. Sedangkan bagi perusahaan atau organisasi, penelitian mengenai kepuasan kerja dilakukan dalam rangka usaha peningkatan produksi dan pengurangan biaya melalui perbaikan sikap dan tingkah laku karayawannya.

Kepuasan kerja berpengaruh 
terhadap kinerja karyawan. Semakin puas karyawan dengan gaji, promosi, rekan kerja, atasan, dan pekerjaan itu sendiri, maka kinerja karyawan yang ditunjukkan melalui kualitas, kuantitas, dan ketepatan waktu akan semakin tinggi.

Menurut Mangkunegara (2016) "pengertian kinerja adalah hasil kerja secara kualitas dan kuantitas yang dicapai oleh seorang pegawai dalam melaksanakan tugasnya sesuai dengan tanggung jawab yang diberikan kepadanya".

Berdasarkan pemaparan yang sudah disampaikan di atas, maka penulis tertarik melakukan penelitian lebih lanjut dengan judul "Pengaruh pengembangan karir dan penempatan terhadap kepuasan kerja yang berdampak pada kinerja karyawan pada PT. Sanco Perdika Pratama di Jakarta".

\section{Rumusan Masalah}

a. Adakah pengaruh secara parsial antara pengembangan karir terhadap kepuasan kerja pada PT. Sanco Perdika Pratama di Jakarta?.

b. Adakah pengaruh secara parsial antara penempatan terhadap kepuasan kerja pada PT. Sanco Perdika Pratama di Jakarta?.

c. Adakah pengaruh secara simultan antara pengembangan karir dan penempatan terhadap kepuasan kerja pada PT. Sanco Perdika Pratama di Jakarta?.

d. Adakah pengaruh antara kepuasan kerja terhadap kinerja karyawan pada PT. Sanco Perdika Pratama di Jakarta ?.

\section{Tujuan Penelitian}

a. Untuk mengetahui pengaruh secara parsial antara Pengembangan karir terhadap kepuasan kerja pada PT. Sanco Perdika Pratama di Jakarta .

b. Untuk mengetahui pengaruh secara parsial antara penempatan terhadap kepuasan kerja pada PT. Sanco Perdika Pratama di Jakarta.

c. Untuk mengetahui pengaruh secara simultan antara Pengembangan karir dan penempatan terhadap kepuasan kerja pada PT. Sanco Perdika Pratama di Jakarta.

d. Untuk mengetahui pengaruh antara kepuasan kerja terhadap kinerja karyawan pada PT. Sanco Perdika Pratama di Jakarta.

\section{TINJAUAN PUSTAKA}

\section{Pengembangan Karir}

Pengembangan

karir menjadi sangat penting dilakukan dalam rangka menumbuhkan semangat kerja pada diri karyawan atau pegawai. Menurut Rivai (2015) mendefinisikan "Pengembangan karier adalah peningkatan peningkatan pribadi yang dilakukan seseorang untuk mencapai suatu rencana karier. Lebih lanjut disampaikan bahwa indikator yang perlu dipertimbangkan dalam pengembangan karir, meliputi sebagai berikut: Kemampuan kerja, Exposure, Kesetiaan Organisasi, Mentor dan Sponsor, Kesempatan-kesempatan untuk tumbuh

\section{Penempatan}

Menurut Hasibuan (2016) dalam Yuniarsih dan Suwatno (2013) mengemukakan 
penempatan karyawan merupakan tindak lanjut dari seleksi, yaitu menempatkan calon pegawai yang diterima (lulus seleksi) pada jabatan/pekerjaan yang membutuhkannya dan sekaligus mendelegasikan authority kepada orang tersebut. Adapun indikator yang digunakan meliputi: Pendidikan, Pengetahuan Kerja, Keterampilan Kerja, Pengalaman Kerja.

\section{Kepuasan Kerja}

Menurut Hariandja (2019:290). "Kepuasan kerja adalah perasaan dan penilaian seorang atas pekerjaannya, khususnya mengenai kondisi kerjanya, dalam hubungannya dengan apakah pekerjaannya mampu memenuhi harapan, kebutuhan dan keinginannya".

\section{Kinerja Karyawan}

Menurut Mangkunegara (2016) pengertian kinerja adalah hasil kerja secara kualitas dan kuantitas yang dicapai oleh seorang pegawai dalam melaksanakan tugasnya sesuai dengan tanggung jawab yang diberikan kepadanya. Adapun indikator yang digunakan sebagai berikut: Kualitas kerja, Kuntitas kerja, Pelaksanaan Tugas, Tanggung Jawab

\section{Model Penelitian}

Menurut pendapat Sugiyono (2018) "Model penelitian merupakan sintesa yang mencerminkan keterkaitan antara variabel yang diteliti dan merupakan tuntunan untuk memecahkan masalah penelitian serta merumuskan hipotesis yang berbentuk bagan alur yang dilengkapi penjelasan kualitatif".

\section{Hipotesis Penelitian}

Menurut Sugiyono (2018) "Hipotesis merupakan jawaban sementara terhadap masalahmasalah, karena sifatnya sementara maka perlu dibuktikan kebenarannya melalui data empirik yang terkumpul". Adapun rumusan hipotesis yang diajukan sebagai berikut:

H1 : Terdapat pengaruh yang signifikan pengembangan karir terhadap kepuasan kerja pada PT. Sanco Perdika Pratama di Jakarta.

H2 : Terdapat pengaruh yang signifikan penempatan terhadap kepuasan kerja pada PT. Sanco Perdika Pratama di Jakarta.

H3 : Terdapat pengaruh yang signifikan pengembangan karir dan penempatan secara simultan terhadap kepuasan kerja pada PT. Sanco Perdika Pratama di Jakarta.

H4 : Terdapat pengaruh yang signifikan kepuasan kerja terhadap kinerja karyawan pada PT. Sanco Perdika Pratama di Jakarta.

\section{METODE PENELITIAN}

\section{Populasi}

Populasi dalam penelitian ini berjumlah 98 responden PT. Sanco Perdika Pratama di Jakarta

\section{Sampel}

Teknik pengambilan sampling dalam penelitian ini adalah samplel jenuh, dimana semua anggota populasi dijasikan sebagai sampel. Dengan demikian sampel dalam penelitian ini berjumlah 98 responden.

\section{Jenis Penelitian}


Jenis penelitian yang dipakai adalah asosiatif, dimana tujuannya adalah untuk mengetahui mencari keterhubungan antara

\section{Teknik Analisis Data}

Dalam menganalisis data digunakan uji instrumen, uji asumsi klasik, regresi, koefisien determinasi dan uji hipotesis.

\section{a. Uji Instrumen}

Pada pengujian ini digunakan uji validitas dan uji reliabilitas.

1) Uji Validitas.

Uji validitas dimaksudkan untuk mengetahui ketepatan data tentang kesesuaian antara yang mau diukur dengan hasil pengukurannya. Untuk melakukan uji validitas dilihat nilai signifikansi 2 tailed dibandingkan dengan 0,05 dengan dengan ketentuan:

1) Jika nilai signifikansi 2 talied < 0,05, maka instrumen valid,

2) Jika nilai signifikansi 2 talied > 0,05, maka instrumen tidak valid,

2) Uji Reliabilitas.

\begin{tabular}{lr}
\multicolumn{1}{c}{ Uji } & reliabilitas \\
merupakan & serangkaian \\
pengukuran & atau \\
serangkaian alat & ukur yang
\end{tabular} memiliki konsistensi bila pengukuran yang dilakukan dengan alat ukur itu dilakukan secara berulang. Instrumen yang baik tidak akan bersifat tendensius mengarahkan responden untuk memilih jawaban tertentu. Adapun kriteria yang digunakan sebagai berikut:
(a)Jika Cronbach's Alpha > 0,600, maka instrumen reliabel.

(b)Jika Cronbach's Alpha < 0,600, maka instrumen tidak reliabel.

\section{b. Uji Asumsi Klasik}

Uji asumsi klasik dimaksudkan untuk mengetahui ketepatan sebuah data. Dalam penelitian ini uji asumsi klasik yang digunakan adalah meliputi: Uji Normalitas, Uji Multikolinearitas, Uji Autokorelasi, dan Uji Heterokedastisitas. Adapun hasilnya sebagai berikut:

1) Uji Normalitas

Uji normalitas digunakan untuk menguji apakah dalam sebuah model regresi, variabel dependen, variabel independen, atau keduanya mempunyai distribusi normal atau tidak. Uji normilitas menggunakan Kolmogorov-Smirnov test, dengan ketentuan:

(a)Jika nilai signifikansi < 0,05 , maka data tidak berdistribusi normal.

(b)Jika nilai signifikansi > 0,05, maka data berdistribusi normal.

2) Uji Multikolinieritas

Uji Multikolinieritas ini bertujuan menguji apakah pada model regresi ditemukan adanya korelasi antar variabel independen. Dalam penelitian ini digunakan batas tolerance dan lawannya, variance inflation factor (VIF) dengan ketentuan: 
(a)Jika nilai nilai tolerance lebih $<1$ dan nilai Variance Inflation Factor (VIF) < dari 1, maka tidak terjadi multikolinieritas.

(b)Jika nilai nilai tolerance lebih > 1 dan nilai Variance Inflation Factor (VIF) > dari 1, maka terjadi multikolinieritas.

3) Uji Autokorelasi

Uji autokorelasi digunakan untuk mengetahui ada atau tidaknya penyimpangan asumsi klasik autokorelasi, yaitu adanya korelasi antar anggota sampel. Dalam penelitian ini digunakan Durbin Watson Test.

4) Uji Heterskedastisitas Uji

Htereoskaedastisitas bertujuan untuk mengetahui apakah dalam model regresi terjadi ketidaksamaan varian dari suatu residual pengamatan ke pengamatan lain. Cara menprediksi ada atau tidaknya

heteroskedastisitas digunakan Glejser Test.

\section{c. Uji Statistik}

\section{1) Regresi Linier}

Analisis regresi liner merupakan suatu teknik statistika yang digunakan untuk mencari persamaan regresi yang bermanfaat untuk meramal nilai variabel dependen berdasarkan nilainilai variabel independen. Dalam penelitian ini digunakan regresi linier berganda.

2) Koefisien Determinasi

Analisis koefisien determinasi dimaksudkan untuk mengetahui besarnya pengaruh antara variabel independen terhadap variabel dependen baik secara parsial maupun simultan.

3) Uji Hipotesis

Pengujian hipotesis dimaksudkan untuk menentukan apakah suatu hipotesis sebaiknya diterima atau ditolak. Dalam penelitian ini digunakan uji $\mathrm{t}$ (Parsial) dan uji F (Simultan).

\section{HASIL PENELITIAN}

\section{Hasil Uji Instrumen}

a. Dari hasil pengujian diperoleh seluruh item kuesioner variabel Pengembangan karir diperoleh nilai signifikansi 2 tailed sebesar $0,000<0,05$, dengan demikian instrumen valid.

b. Dari hasil pengujian diperoleh seluruh item kuesioner variabel penempatan diperoleh nilai signifikansi 2 tailed sebesar $0,000<0,05$, dengan demikian instrumen valid.

c. Dari hasil pengujian diperoleh seluruh item kuesioner variabel kepuasan kerja diperoleh nilai signifikansi 2 tailed sebesar $0,000<0,05$, dengan demikian instrumen valid.

d. Dari hasil pengujian reliabilitas, diperoleh hasil sebagai berikut: 
Tabel 1. Hasil Pengujian Reliabilitas

\begin{tabular}{|c|c|c|c|}
\hline Variabel & $\begin{array}{c}\text { Cronbach's } \\
\text { Alpha }\end{array}$ & $\begin{array}{c}\text { Standar Kritis } \\
\text { Alpha }\end{array}$ & Keterangan \\
\hline Pengembangan Karir (X1) & 0,640 & 0,600 & Reliabel \\
\hline Penempatan (X2) & 0,638 & 0,600 & Reliabel \\
\hline Kepuasan Kerja (Y) & 0,616 & 0,600 & Reliabel \\
\hline Kinerja Karyawan (Z) & 0,627 & 0,600 & Reliabel \\
\hline
\end{tabular}

Berdasarkan hasil pengujuan di atas, keseluruhan variabel Pengembangan karir (X1), penempatan (X2), kepuasan kerja (Y) dan kinerja karyawan (Z) diperoleh nilai cronbach alpha lebih besar dari 0,600. Dengan demikian dinyatakan reliabel.

\section{Hasil Uji Asumsi Klasik}

\section{a. Uji Normalitas}

Hasil uji normalitas dengan alat uji KolmogorovSmirnov Test, sebagai berikut:

Tabel 2. Hasil Normalitas

\section{Kolmogorov-Smirnov Test}

Tests of Normality

Kolmogorov-

Smirnova $\quad$ Shapiro-Wilk

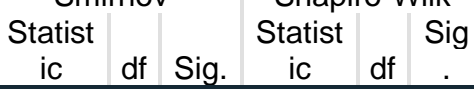

\begin{tabular}{|c|c|c|c|c|c|c|}
\hline $\begin{array}{l}\text { Kepuas } \\
\text { an Kerja } \\
\text { (Y) }\end{array}$ & .075 & $\begin{array}{l}9 \\
8\end{array}$ & $\begin{array}{r}.20 \\
0^{*}\end{array}$ & .974 & $\begin{array}{l}9 \\
8\end{array}$ & $\begin{array}{r}.04 \\
8\end{array}$ \\
\hline
\end{tabular}

\section{Berdasarkan}

hasil pengujian pada tabel di atas diperoleh nilai signifikansi 0,200 dimana nilai tersebut lebih besar dari nilai $\alpha=0,050$ atau $(0,200>0,050)$. Dengan demikian maka asumsi distribusi persamaan pada uji ini adalah normal.

\section{b. Uji Multikonilieritas}

Uji multikolinearitas dilakukan dengan melihat nilai Tolerance Value dan Variance Inflation Factor (VIF). Adapun hasil pengujiannya sebagai berikut:

Tabel 3. Hasil Uji Multikolinieritas dengan Collinierity Statistic.

\begin{tabular}{|c|c|c|c|c|c|}
\hline \multirow[b]{2}{*}{ Model } & \multicolumn{2}{|c|}{$\begin{array}{l}\text { Coefficients }^{\mathbf{a}} \\
\text { Unstandardized } \\
\text { Coefficients }\end{array}$} & \multirow{2}{*}{$\begin{array}{c}\text { Standardized } \\
\text { Coefficients } \\
\text { Beta }\end{array}$} & \multicolumn{2}{|c|}{$\begin{array}{c}\text { Collinearity } \\
\text { Statistics }\end{array}$} \\
\hline & $\mathrm{B}$ & Std. Error & & Tolerance & VIF \\
\hline $\begin{array}{ll}1 & \text { (Constant) }\end{array}$ & 9.489 & 3.067 & & & \\
\hline Pengembangan Karir (X1) & .378 & .083 & .401 & .685 & 1.460 \\
\hline Penempatan (X2) & .395 & .088 & .395 & .685 & 1.460 \\
\hline
\end{tabular}

a. Dependent Variable: Kepuasan Kerja (Y)

Berdasarkan hasil pengujian pada tabel di atas nilai tolerance masing-masing variabel bebas yaitu $0,685<1,0$ dan nilai Variance Inflation Factor (VIF) sebesar $1,460<10$, dengan demikian model regresi ini tidak terjadi multikolinearitas.

\section{c. Uji Autokorelasi}

Pengujian dilakukan dengan alat uji Darbin-Watson (DW test). Adapun hasil pengujiannya sebagai berikut: 
Tabel 4. Hasil Uji Autokorelasi Model Summaryb

\begin{tabular}{lc|c|c|c|c} 
& & & & Std. & \\
& & & Adjust & $\begin{array}{c}\text { Error } \\
\text { Mod }\end{array}$ & Durbi \\
ed R & of the & $n-$ \\
el & $\mathrm{R}$ & $\begin{array}{c}\text { Squa } \\
\text { re }\end{array}$ & $\begin{array}{c}\text { Squar } \\
\text { Estima }\end{array}$ & $\begin{array}{c}\text { Wats } \\
\text { te }\end{array}$ & on \\
\hline 1 & .70 & .495 & .484 & 2.479 & 1.886 \\
& $4^{a}$ & & & & \\
\hline
\end{tabular}

a. Predictors: (Constant), Penempatan (X2), Pengembangan Karir (X1)

b. Dependent Variable: Kepuasan Kerja (Y)

Hasil pengujian pada tabel di
Watson sebesar 1,886 nilai tersebut berada diantara interval 1.550 - 2.460. Dengan demikian model regresi dinyatakan tidak ada gangguan autokorelasi.

\section{d. Uji Heteroskesdastisitas}

Pengujian dilakukan dengan alat uji Glejser Test Model. Adapun hasil pengujiannya sebagai berikut:

atas diperoleh nilai Durbin-

Tabel 5. Hasil Uji Heteroskesdastisitas dengan Glejser Test Model

\section{Coefficients $^{a}$}

\begin{tabular}{|c|c|c|c|c|c|}
\hline \multirow[b]{2}{*}{ Model } & \multicolumn{2}{|c|}{$\begin{array}{l}\text { Unstandardized } \\
\text { Coefficients }\end{array}$} & \multirow{2}{*}{$\begin{array}{l}\text { Standardized } \\
\text { Coefficients } \\
\text { Beta }\end{array}$} & \multirow{2}{*}{4} & \multirow[b]{2}{*}{ Sig. } \\
\hline & B & Std. Error & & & \\
\hline $\begin{array}{ll}1 & \text { (Constant) }\end{array}$ & 4.745 & 1.902 & & 2.495 & .014 \\
\hline Pengembangan Karir (X1) & -.094 & .051 & -.223 & -1.834 & .070 \\
\hline Penempatan (X2) & .019 & .055 & .042 & .343 & .732 \\
\hline
\end{tabular}

a. Dependent Variable: RES2

Hasil pengujian dengan menggunakan uji glejser diperoleh nilai Sig. $>0,050$. Dengan demikian regression model tidak ada gangguan heteroskesdastisitas.

3. Analisis Deskriptif

Pada pengujian

ini digunakan untuk mengetahui skor minimum dan maksimum skor tertinggi, ratting score dan standar deviasi dari masing-masing variabel. Adapun hasilnya sebagai berikut:

Tabel 6. Hasil Analisis Descriptive Statistics

Descriptive Statistics

\begin{tabular}{l|r|r|r|r|r} 
& N & Minimum & Maximum & Mean & Std. Deviation \\
\hline Pengembangan Karir (X1) & 98 & 30 & 46 & 37.85 & 3.665 \\
\hline Penempatan (X2) & 98 & 31 & 45 & 38.29 & 3.455 \\
\hline Kepuasan Kerja (Y) & 98 & 32 & 46 & 38.91 & 3.452 \\
\hline Kinerja Karyawan (Z) & 98 & 32 & 45 & 38.95 & 3.319 \\
\hline Valid N (listwise) & 98 & & & & \\
\hline
\end{tabular}

Pengembangan karir diperoleh varians minimum sebesar 30 dan varians maximum 46 dengan ratting score sebesar 3,785 dengan standar deviasi 3,665 .

Penempatan diperoleh varians minimum sebesar 31 dan varians maximum 45 dengan ratting score sebesar 3,829 dengan standar deviasi 3,455.
Kepuasan kerja diperoleh varians minimum sebesar 32 dan varians maximum 46 dengan ratting score sebesar 3,891 dengan standar deviasi 3,452.

Kinerja karyawan diperoleh varians minimum sebesar 32 dan varians maximum 45 dengan ratting score sebesar 3,895 dengan standar deviasi 3,319. 


\section{Analisis Kuantitatif}

Pada analisis ini dimaksudkan untuk mengetahui pengaruh variabel independen terhadap variabel dependen. Adapun hasil pengujian sebagai berikut:

\section{a. Analisis Regresi Linier Berganda \\ Uji regresi ini} dimaksudkan untuk mengetahui perubahan variabel dependen jika variabel independen mengalami perubahan. Adapun hasil pengujiannya sebagai berikut:

Tabel 7. Hasil Pengujian Regresi Linier Berganda

\begin{tabular}{|c|c|c|c|c|c|}
\hline \multirow[b]{2}{*}{ Model } & \multicolumn{2}{|c|}{$\begin{array}{l}\text { Coefficients }^{\mathbf{a}} \\
\text { Unstandardized } \\
\text { Coefficients }\end{array}$} & \multirow{2}{*}{$\begin{array}{c}\text { Standardized } \\
\text { Coefficients } \\
\text { Beta } \\
\end{array}$} & \multirow[b]{2}{*}{$\mathrm{t}$} & \multirow[b]{2}{*}{ Sig. } \\
\hline & B & Std. Error & & & \\
\hline $\begin{array}{ll}1 & \text { (Constant) } \\
\end{array}$ & 9.489 & 3.067 & & 3.094 & .003 \\
\hline Pengembangan Karir (X1) & .378 & .083 & .401 & 4.557 & .000 \\
\hline Penempatan (X2) & .395 & .088 & .395 & 4.483 & .000 \\
\hline
\end{tabular}

a. Dependent Variable: Kepuasan Kerja $(\mathrm{Y})$

Berdasarkan hasil pengujian pada tabel di atas, diperoleh persamaan regresi $\mathrm{Y}$ $=9,489+0,378 \mathrm{X} 1+0,395 \mathrm{X} 2$. Dari persamaan tersebut dijelaskan sebagai berikut:

1) Konstanta sebesar 9,489 diartikan jika Pengembangan karir dan penempatan tidak ada, maka telah terdapat nilai kepuasan kerja sebesar 9,489 point.

2) Koefisien regresi Pengembangan karir sebesar 0,378, angka ini positif artinya setiap ada peningkatan Pengembangan karir sebesar 0,378 point maka kepuasan kerja juga akan mengalami peningkatan sebesar 0,378 point.

3) Koefisien regresi penempatan sebesar 0,395, angka ini positif artinya setiap ada peningkatan penempatan sebesar 0,395 point maka kepuasan kerja juga akan mengalami peningkatan sebesar 0,395 point.

b. Analisis

Determinasi

Analisis

Koefisien determinasi dimaksudkan untuk mengetahui besarnya persentase pengaruh dari variabel independen terhadap variabel dependen baik secara parsial maupun simultan. Adapun hasil pengujian sebagai berikut:

Tabel 8. Hasil Pengujian

Koefisien Determinasi

Pengembangan Karir Terhadap

Kepuasan Kerja.

Model Summary

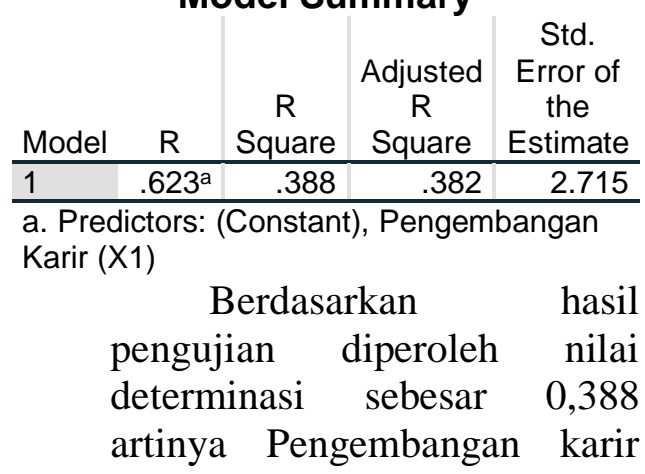


memiliki kontribusi pengaruh sebesar $38,8 \%$ terhadap kepuasan kerja.

Tabel 9. Hasil Pengujian

Koefisien Determinasi

Penempatan Terhadap Kepuasan Kerja.

Model Summary

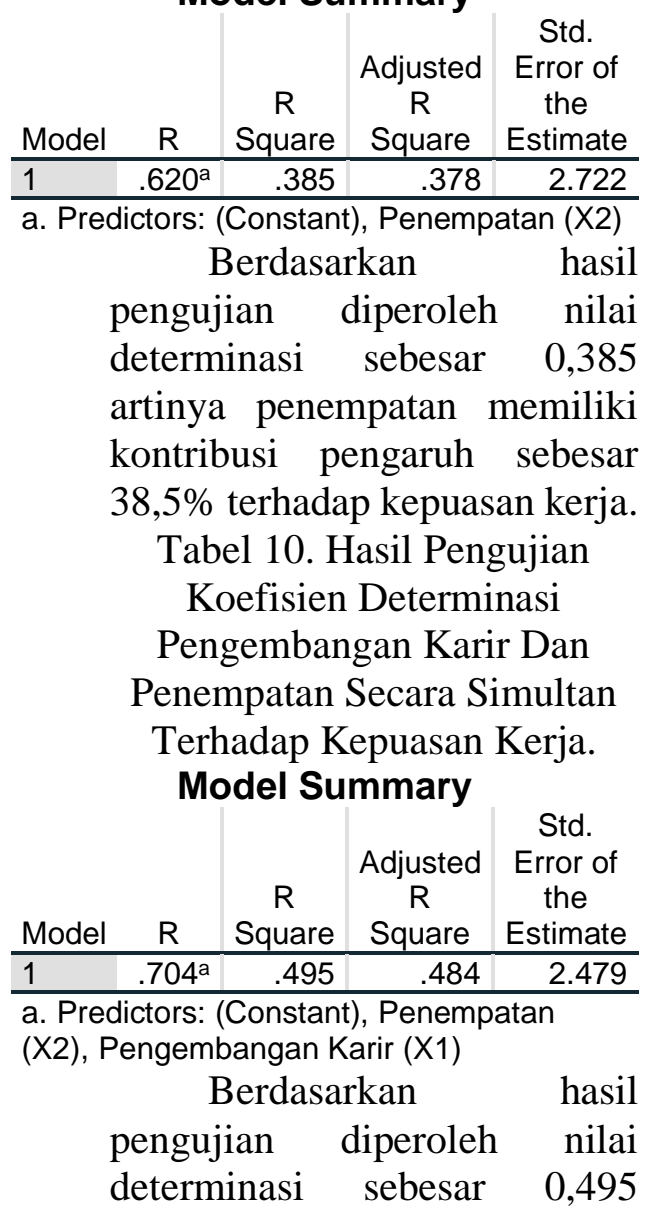

artinya Pengembangan karir dan penempatan secera simultan memiliki kontribusi pengaruh sebesar 49,5\% terhadap kepuasan kerja, sedangkan sisanya sebesar 50,5\% dipengaruhi faktor lain.

Tabel 11. Hasil Pengujian Koefisien Determinasi

Kepuasan Kerja Terhadap Kinerja Karyawan. Model Summary

\begin{tabular}{lc|c|c|c} 
Model & $\mathrm{R}$ & $\mathrm{R}$ & $\begin{array}{c}\text { Adjusted } \\
\mathrm{R}\end{array}$ & $\begin{array}{c}\text { Std. } \\
\text { Error of } \\
\text { the } \\
\text { Estimate }\end{array}$ \\
\hline 1 & $.630^{\mathrm{a}}$ & .397 & .391 & 2.591 \\
\hline a. Predictors: (Constant), Kepuasan Kerja
\end{tabular}
(Y)

Berdasarkan hasil pengujian diperoleh nilai determinasi sebesar 0,397 artinya kepuasan kerja memiliki kontribusi pengaruh sebesar $39,7 \%$ terhadap kinerja karyawan.

c. Uji Hipotesis Uji hipotesis Parsial (Uji t)

Pengujian hipotesis dengan uji $\mathrm{t}$ digunakan untuk mengetahui hipotesis parsial mana yang diterima. Adapun hasil pengujian sebagai berikut:

Tabel 12. Hasil Uji Hipotesis Pengembangan Karir Terhadap Kepuasan

Kerja.

Coefficients $^{a}$

Unstandardized

Coefficients

\begin{tabular}{|c|c|c|c|c|c|}
\hline \multirow[b]{2}{*}{ Model } & \multicolumn{2}{|c|}{ Coefficients } & \multirow{2}{*}{$\begin{array}{l}\text { Coefficients } \\
\text { Beta }\end{array}$} & \multirow[b]{2}{*}{$t$} & \\
\hline & B & Std. Error & & & \\
\hline 1 (Constant) & 16.694 & 2.860 & & 5.838 & \\
\hline Pengembangan $\mathrm{K}$ & .587 & 5 & $6 ?$ & 7804 & \\
\hline
\end{tabular}

a. Dependent Variable: Kepuasan Kerja $(\mathrm{Y})$

Berdasarkan hasil pengujian pada tabel di atas, diperoleh nilai $\mathrm{t}$ hitung $>\mathrm{t}$ tabel atau $(7,804>1,985)$, dengan

demikian hipotesis yang diajukan bahwa terdapat pengaruh yang signifikan antara Pengembangan karir terhadap 
kepuasan kerja diterima.

Tabel 13. Hasil Uji Hipotesis Penempatan Terhadap Kepuasan Kerja.

\begin{tabular}{|c|c|c|c|c|c|}
\hline \multirow[b]{2}{*}{ Model } & $\begin{array}{r}\text { Unste } \\
\text { Co }\end{array}$ & $\begin{array}{l}\text { efficients } \\
\text { dardized } \\
\text { icients }\end{array}$ & \multirow[t]{2}{*}{$\begin{array}{c}\text { Standardized } \\
\text { Coefficients } \\
\text { Beta }\end{array}$} & \multirow[b]{2}{*}{$\mathrm{t}$} & \multirow[b]{2}{*}{ Sig. } \\
\hline & B & Std. Error & & & \\
\hline $\begin{array}{ll}1 & \text { (Constant) } \\
\end{array}$ & 15.184 & 3.075 & & 4.937 & .000 \\
\hline Penempatan (X2) & .620 & .080 & .620 & 7.746 & .000 \\
\hline
\end{tabular}

a. Dependent Variable: Kepuasan Kerja (Y)

Berdasarkan hasil pengujian pada tabel di atas, diperoleh nilai $\mathrm{t}$ hitung $>\mathrm{t}$ tabel atau $(7,746>1,985)$, dengan demikian hipotesis yang

Tabel 14. Hasil Uji Hipotesis Kepuasan Kerja Terhadap Kinerja Karyawan.

\begin{tabular}{|c|c|c|c|c|c|c|}
\hline \multirow[b]{2}{*}{ Mode } & & $\begin{array}{r}\text { Co } \\
\text { Unsta } \\
\text { Coe }\end{array}$ & $\begin{array}{l}\text { fficients } \\
\text { dardized } \\
\text { ficients }\end{array}$ & $\begin{array}{l}\text { Standardized } \\
\text { Coefficients }\end{array}$ & \multirow[b]{2}{*}{$t$} & \multirow[b]{2}{*}{ Sig. } \\
\hline & & $\mathrm{B}$ & Std. Error & Beta & & \\
\hline & (Constant) & 15.374 & 2.976 & & 5.166 & .000 \\
\hline & Kepuasan Kerja (Y) & .606 & .076 & .630 & 7.953 & .000 \\
\hline
\end{tabular}

a. Dependent Variable: Kinerja Karyawan (Z)

Berdasarkan hasil pengujian pada tabel di atas, diperoleh nilai t hitung $>\mathrm{t}$ tabel atau $(7,953>1,985)$, dengan demikian hipotesis yang diajukan bahwa terdapat pengaruh yang signifikan antara kepuasan kerja terhadap kinerja karyawan diterima. diajukan bahwa terdapat pengaruh yang signifikan antara penempatan terhadap kepuasan kerja diterima.

Tabel 15. Hasil Uji Hipotesis Pengembangan karir dan Penempatan Secara Simultan Terhadap Kepuasan Kerja.

\begin{tabular}{|c|c|c|c|c|c|c|}
\hline \multirow{2}{*}{\multicolumn{2}{|c|}{ Model }} & \multicolumn{3}{|c|}{ ANOVA $^{a}$} & \multirow{3}{*}{$\begin{array}{c}\mathrm{F} \\
46.557\end{array}$} & \multirow{3}{*}{$\frac{\text { Sig. }}{.000^{\mathrm{b}}}$} \\
\hline & & Sum of Squares & df & Mean Square & & \\
\hline 1 & Regression & 572.289 & 2 & 286.145 & & \\
\hline & Residual & 583.884 & 95 & 6.146 & & \\
\hline & Total & 1156.173 & 97 & & & \\
\hline
\end{tabular}

a. Dependent Variable: Kepuasan Kerja $(Y)$

b. Predictors: (Constant), Penempatan (X2), Pengembangan Karir (X1)

Berdasarkan hasil pengujian pada tabel di atas, diperoleh nilai $\mathrm{F}$ hitung $>\mathrm{F}$ tabel atau $(46,557>2,700)$, dengan demikian hipotesis keempat yang diajukan bahwa terdapat pengaruh yang signifikan antara Pengembangan karir dan penempatan secara simultan terhadap kepuasan kerja diterima. 
PEMBAHASAN

HASIL PENELITIAN

1. Pengaruh Pengembangan Karir Terhadap Kepuasan Kerja

Pengembangan karir berpengaruh signifikan terhadap kepuasan kerja dengan nilai koefisien determinasi sebesar $38,8 \%$. Pengujian hipotesis diperoleh nilai $\mathrm{t}$ hitung $>\mathrm{t}$ tabel atau $(7,804>1,985)$. Dengan demikian hipotesis yang diajukan bahwa terdapat berpengaruh signifikan antara Pengembangan karir terhadap kepuasan kerja diterima.

2. Pengaruh

Penempatan Terhadap Kepuasan Kerja

Penempatan berpengaruh signifikan terhadap kepuasan kerja dengan nilai koefisien determinasi sebesar $38,5 \%$. Pengujian hipotesis diperoleh nilai t hitung > $t$ tabel atau $(7,746>1,985)$. Dengan demikian hipotesis yang diajukan bahwa terdapat berpengaruh signifikan antara penempatan terhadap kepuasan kerja diterima.

3. Pengaruh Pengembangan Karir Dan Penempatan Terhadap Kepuasan Kerja

Pengembangan karir dan penempatan berpengaruh signifikan terhadap kepuasan kerja dengan diperoleh persamaan regresi $\mathrm{Y}=9,489+0,378 \mathrm{X} 1+$ $0,395 \times 2$, dengan nilai koefisien determinasi sebesar $49,5 \%$ sedangkan sisanya sebesar $50,5 \%$ dipengaruhi faktor lain. Pengujian hipotesis diperoleh nilai $\mathrm{F}$ hitung $>$ F tabel atau $(46,557>2,700)$. Dengan demikian hipotesis yang diajukan bahwa terdapat berpengaruh signifikan antara
Pengembangan karir dan penempatan terhadap kepuasan kerja diterima.

4. Pengaruh Kepuasan Kerja Terhadap Kinerja Karyawan

Kepuasan kerja berpengaruh signifikan terhadap kinerja karyawan dengan nilai koefisien determinasi sebesar $39,7 \%$. Pengujian hipotesis diperoleh nilai t hitung > t tabel atau (7,953 > $1,985)$. Dengan demikian hipotesis yang diajukan bahwa terdapat berpengaruh signifikan antara kepuasan kerja terhadap kinerja karyawan diterima.

\section{KESIMPULAN DAN SARAN}

\section{Kesimpulan}

a. Pengembangan

karir berpengaruh signifikan terhadap kepuasan kerja dengan kontribusi pengaruh sebesar $38,8 \%$. Uji hipotesis diperoleh nilai $\mathrm{t}$ hitung $>\mathrm{t}$ tabel atau $(7,804>1,985)$.

b. Penempatan berpengaruh signifikan terhadap kepuasan kerja dengan kontribusi pengaruh sebesar $38,5 \%$. Uji hipotesis diperoleh nilai $\mathrm{t}$ hitung > t tabel atau $(7,746>$ 1,985).

c. Pengembangan karir dan penempatan secara simultan berpengaruh signifikan terhadap kepuasan kerja dengan kontribusi pengaruh sebesar $49,5 \%$ sedangkan sisanya sebesar 50,5\% dipengaruhi faktor lain. Uji hipotesis diperoleh nilai $\mathrm{F}$ hitung $>\mathrm{F}$ tabel atau $(46,557>2,700)$.

d. Kepuasan kerja berpengaruh signifikan terhadap kinerja karyawan dengan kontribusi 
pengaruh sebesar $39,7 \%$. Uji hipotesis diperoleh nilai $\mathrm{t}$ hitung > t tabel atau $(7,953>$ $1,985)$.

\section{Saran}

a.Perusahaan harus memiliki program pengembangan karir bagi karyawan untuk memastikan bahwa karyawan tepat didalam pekerjaannya

b.Perusahaan harus secara selektif dalam menempatkan karyawan sesuai dengan bidang keahliannya.

c. Perusahaan sebaiknya menambahkan kebijakan pemberian insentif atau sejenisnya untuk merangsang karyawan mencapai kepuasan kerja

d. Kinerja perusahaan dapat ditingkatkan dengan memberdayakan karyawan dengan menegakkan peraturan yang baik dan pemberian pengembagan karir yang lebih inten lagi.

\section{DAFTAR PUSTAKA}

Algifari. (2015). "Analisis Regresi untuk Bisnis dan Ekonomi". Yogyakarta: BPFE.

AM, E. N., et al. (2020). Pengaruh Pendidikan Dan Pelatihan Terhadap Kinerja Pegawai Direktorat Standarisasi Dan Pengendalian Mutu Kementerian

Perdagangan. Diklat Review: Jurnal manajemen pendidikan dan pelatihan, 4(3), 220-226.

Arikunto, Suharsimi (2014). "Prosedur Penelitian Suatu Pendekatan Praktek". Jakarta:
Rineka Cipta.

Damayanti, D., et al. (2021). Peran

Work Overload, Work Environment, Work Family Conflict \& Work Stress Terhadap Job Performance. Jurnal Ilmiah Wahana Pendidikan, 7(3), 192206.

Goklas, A., et al. (2021). Management Of Organizational Performance: The Role Of Human Resource Management Strategy. Jurnal

Ad'ministrare, 8(1), 245-254.

Imam Ghozali (2017). "Aplikasi Analisis Multivariate Dengan Program SPSS”. Edisi Kelima. Semarang: Badan Penerbit Undip.

Istijanto (2014) "Riset Sumber Daya Manusia”. Jakarta: PT. Gramedia Pustaka

Kosasih, et al. (2021). Pengaruh Lingkungan Kerja Dan Disiplin Kerja Terhadap Produktivitas Karyawan Pada PT. Graha Curah Niaga Di Tangerang. Jurnal Administrasi Bisnis (JUBIS). 1(1). 1-10

Kosasih, K., et al. (2020). The Effect of Compensation and Service Period on Employee Performance at PT. Infomedia Nusantara Branch Bandung. Kontigensi: Jurnal Ilmiah Manajemen, 8(2), 147154.

Kustini, E., et al. (2021). Pengaruh Keterampilan Kerja Dan Lingkungan Kerja Terhadap Kinerja Karyawan Pada PT. Garuda Daya Pratama Sejahtera 
(Garuda

Group). Jurnal

Indonesia

PERKUSI, 1(3), 305-314.

Nurjaya, N., et al. (2021). Pengaruh

Kompetensi Sumber Daya

Manusia Dan Kemampuan

Pemanfaatan Teknologi

Terhadap Kinerja Aparatur

Desa Pada Kantor Kepala Desa

Di Kabupaten Gunungkidul, Yogyakarta. JENIUS (Jurnal Ilmiah Manajemen Sumber Daya Manusia), 4(3), 332-346.

Rawi, R. D. P. (2017). Analisis Hubungan Motivasi Terhadap Kinerja Pegawai (Studi Kasus Pada Kantor Kecamatan Ruing
Kabupaten Ngada Ntt). Jurnal Noken: Ilmu-Ilmu Sosial, 2(2), 15-28.

Santoso, Singgih (2015). "Menguasai Statistik Multivariat”. Jakarta: PT Elex Media Komputindo.

Sudjana (2014) "Metode Statistika”, Bandung: Tarsido.

Sugiyono (2017), "Metode Penelitian Administrasi : dilengkapi dengan Metode $R$ \& D”. Bandung: Alfabeta.

Suwanto, S., et al. (2021). Pengaruh Motivasi Dan Pengalaman Kerja Terhadap Produktivitas Karyawan Pada Happy Restaurant Di Bandung. Jurnal Ekonomi Efektif, 3(4), 546-554. 